DOI: $10.15193 /$ zntj/2019/119/281

\author{
KRZYSZTOF GODULA, BARBARA CZERNIEJEWSKA-SURMA, \\ IZABELA DMYTRÓW, DOMINIKA PLUST, ORINA SURMA
}

\title{
MOŻLIWOŚCI ZASTOSOWANIA BLONNIKA POKARMOWEGO DO PRODUKCJI ŻYWNOŚCI FUNKCJONALNEJ
}

\author{
Streszczenie
}

Dynamizacja przemysłu spożywczego w zakresie projektowania nowej lub wzbogaconej żywności i poszerzania asortymentu produktów na rynku jest elementem rywalizacji zarówno pomiędzy branżami przemysłu spożywczego, jak i poszczególnymi producentami. Producenci dążą do zaoferowania konsumentom jak najszerszej gamy produktów korzystnych pod względem wartości odżywczej, właściwości prozdrowotnych i funkcjonalnych, o przedłużonym terminie przydatności do spożycia, a także atrakcyjnych cenowo. Taka strategia rynkowa pozwala zdobyć przewagę konkurencyjną, jak również promować stosowanie najnowszych rozwiązań technologicznych. Wzrost zainteresowania i świadomości konsumentów w zakresie prawidłowego żywienia spowodował rozszerzenie wymagań dotyczących jakości, w tym wartości odżywczej żywności. Wiąże się to z koniecznością zmian w procesach produkcji, co w efekcie ma usatysfakcjonować jak największą liczbę konsumentów.

Błonnik pokarmowy jest przykładem składnika wzbogacającego środki spożywcze, który w ostatnim czasie jest przedmiotem wzmożonego zainteresowania zarówno ze strony producentów, jak i konsumentów, którzy uznają go przede wszystkim za prozdrowotny składnik żywności. W ubiegłym wieku stosowanie dodatku błonnika pokarmowego do żywności bardzo często wiązało się z powstawaniem niekorzystnej tekstury produktu. Obecnie produkowane są nowoczesne preparaty błonnikowe, które korzystnie wpływają na teksturę, właściwości funkcjonalne oraz sensoryczne żywności i charakteryzują się takimi właściwościami, jak: wiązanie wody, zwiększanie objętości produktów, neutralny zapach oraz smak czy możliwość stosowania jako zamiennika tłuszczu.

W pracy omówiono historię i podział żywności funkcjonalnej, definicję i podział błonnika pokarmowego oraz możliwości zastosowania tego składnika w projektowaniu i wzbogacaniu produktów żywnościowych.

Słowa kluczowe: żywność funkcjonalna, składniki bioaktywne, błonnik pokarmowy, preparaty błonnikowe, projektowanie żywności

Mgr inż. K. Godula, dr hab. inż. I. Dmytrów, Zakład Technologii Mleczarskiej i Przechowalnictwa Żywności, dr hab. inż. B. Czerniejewska-Surma, prof. nadzw., dr inż. D. Plust, Zaktad Towaroznawstwa i Oceny Jakości, Wydz. Nauk o Żywności i Rybactwa, Zachodniopomorski Uniwersytet Technologiczny w Szczecinie, ul. Papieża Pawła VI 3, 71-459 Szczecin, dr inż. O. Surma, Katedra Dietetyki i Kosmetologii, Wydz. Kultury Fizycznej i Ochrony Zdrowia, Państwowa Wyższa Szkoła Zawodowa w Koninie, ul.Przyjaźni 1,62-510 Konin. Kontakt: krzysztof.godula@zut.edu.pl 


\section{Wprowadzenie}

Żywność i żywienie to dwa pojęcia, których definicje nieustannie ulegają modyfikacji. Wraz ze zmieniającymi się oczekiwaniami konsumentów w zakresie żywności aktualizacji ulega również piramida zdrowego żywienia. Konsument oczekuje od współczesnej żywności prozdrowotnego działania, a nie tylko dostarczenia odpowiedniej ilości składników odżywczych i wartości energetycznej. Świadomość korzyści dla organizmu wynikających z wyboru tej grupy produktów zwiększa się dzięki coraz szerszemu asortymentowi i kampaniom reklamowym promującym żywność prozdrowotną. Jej powstanie jest wynikiem wykorzystania w praktyce wiedzy naukowej i ma znacząco wpływać na zdrowie człowieka, jak podkreślają Cygan i wsp. [6]. Jednym z czynników rozwoju żywności funkcjonalnej jest starzenie się społeczeństwa oraz związane z tym wzrastające koszty ochrony zdrowotnej. Dzięki postępowi nauki można mówić o tzw. żywności projektowanej. Oznacza to dostosowanie jej do potrzeb indywidualnych konsumentów, zarówno ludzi zdrowych, jak i cierpiących na różne schorzenia [4].

Rozwój technologii żywności i dostosowywanie produktów do potrzeb konsumenta doprowadziły swego czasu do popularyzacji spożycia artykułów spożywczych, które nie zawierały w swoim składzie substratów nietrawionych przez organizm człowieka. W późniejszym czasie zostało to jednak uznane za jeden z czynników rozwoju przewlekłych chorób niezakaźnych, czyli tzw. chorób cywilizacyjnych. Obecnie świadomość tego, jak duże jest znaczenie błonnika w żywieniu człowieka, plasuje ten związek wśród bardzo ważnych składników bioaktywnych przyczyniających się do poprawy stanu zdrowia $[22,32,38]$.

\section{Historia żywności funkcjonalnej}

Martirosyan i Singh [28] oraz Borycka [4] podają, że teoria żywności funkcjonalnej sięga początków filozofii. Hipokrates (460 - 377 p.n.e.) stwierdzil, że żywność może być lekiem, a lek - żywnością. Idea żywności funkcjonalnej odpowiada temu twierdzeniu, ponieważ zakłada, że taka żywność powinna być lekarstwem. Pierwsza koncepcja żywności funkcjonalnej została sformułowana w 1984 r. w Japonii przez Ministerstwo Edukacji, Nauki i Kultury (Ministry of Education, Science and CultureMESC). W 1991 roku Japończycy jako pierwsi na świecie zatwierdzili ten rodzaj żywności, a pierwszym produktem funkcjonalnym, który został wprowadzony na rynek był ryż o właściwościach hipoalergicznych [28].

W 2001 roku rozszerzono pojęcie żywności funkcjonalnej o żywność specjalną, którą podzielono na żywność aprobatywnie wpływającą na organizm (deklaracja ta musi spełniać warunki Ministerstwa Zdrowia) oraz na żywność z oświadczeniami żywieniowymi i zdrowotnymi (oświadczenie musi spełniać wymagania Rozporządzenia 
WE 1924/2006 [48]). W Europie podjęto się udoskonalenia składu żywności funkcjonalnej poprzez zmianę technologii produkcji czy stosowane dodatki w celu uzyskania korzystniejszego wpływu zdrowotnego na organizm człowieka. Procesy technologiczne żywności funkcjonalnej są stale doskonalone [25]. Niestety ceny tej żywności wciąż znacząco przewyższają wartość przemysłowo produkowanych wyrobów.

\section{Składniki bioaktywne}

Żywność funkcjonalna jest nośnikiem substancji bioaktywnych, czyli składników przeważnie nieodżywczych, wpływających pozytywnie na kondycję i witalność organizmu [32, 40, 41]. Do składników funkcjonalnych zaliczane są m.in. błonnik pokarmowy, bakterie probiotyczne, prebiotyki (w tym oligosacharydy), przeciwutleniacze, flawonoidy, wielonienasycone kwasy tłuszczowe, witaminy, składniki mineralne i inne [40, 41]. Spośród nich na szczególną uwagę zasługuje błonnik pokarmowy, który wykazuje pozytywny wpływ na procesy metaboliczne i fizjologiczne zachodzące w organizmie człowieka. Istotny wpływ błonnika pokarmowego związany jest z jego profilaktycznym działaniem na niektóre $\mathrm{z}$ chorób przewodu pokarmowego, układu krwionośnego i serca. Głównym źródłem błonnika pokarmowego są produkty zbożowe, w tym otręby pszenne oraz warzywa i owoce $[32,47]$.

\section{Podział żywności funkcjonalnej}

Jak wskazuje Grajeta [18], podział żywności funkcjonalnej wynika z dwóch zasadniczych kryteriów. Pierwszym kryterium podziału jest jej unikalny skład, drugim zaspokajanie potrzeb żywieniowych człowieka. Ze względu na pierwsze kryterium żywność funkcjonalną dzieli się dodatkowo na żywność: wysokobłonnikową, probiotyczną, wzbogacaną, niskoenergetyczną oraz niskocholesterolową. Drugie kryterium dotyczy podziału żywności na żywność zmniejszającą ryzyko rozwoju chorób (np. chorób nowotworowych, chorób układu krążenia czy osteoporozy) i żywność specjalnego przeznaczenia żywieniowego (dla kobiet ciężarnych i karmiących, młodzieży w czasie dynamicznego wzrostu, sportowców, osób z zaburzeniami metabolicznymi czy osób narażonych na silny stres) $[18,28]$.

\section{Skład błonnika pokarmowego}

Błonnik pokarmowy, zwany inaczej włóknem pokarmowym, jest elementem strukturalnym roślin, który w przewodzie pokarmowym człowieka nie jest trawiony i wchłaniany. Przez długi czas błonnik uznawany był za bezwartościowy składnik pokarmu. W jego skład, poza elementami ścian komórkowych roślin, wchodzą również: śluzy, gumy roślinne, skrobia oporna, polidekstroza oraz nietrawione oligosacharydy [10, 22, 29, 32]. Jak podają Westenbring i wsp. [44], błonnik pokarmowy dzieli się na 
frakcje rozpuszczalne i nierozpuszczalne w wodzie. Do frakcji rozpuszczalnych zalicza się: pektyny, ß-glukany, gumy i śluzy. Z kolei do frakcji nierozpuszczalnych należą: celuloza, ligniny i hemicelulozy.

\section{Podział błonnika pokarmowego}

Włókno pokarmowe dzieli się na: polisacharydy nieskrobiowe (celuloza), polisacharydy niecelulozowe (hemicelulozy, pektyny, polisacharydy roślin morskich, gumy i śluzy roślinne), ligniny, polisacharydy zmienione technologicznie (skrobia oporna) i polisacharydy syntetyczne [21, 22, 29].

Celuloza, jak i jej pochodne, zaliczana jest do hydrokoloidów polisacharydowych naturalnych oraz poddawanych częstym modyfikacjom. W roślinach wyższych celuloza jest głównym materiałem strukturalnym. Jak podają Grodzka i Krygier [19], celuloza została użyta jako substytut żelatyny po raz pierwszy w Niemczech w czasie I wojny światowej. Współcześnie celuloza znajduje wszechstronne zastosowanie w żywności, przemyśle kosmetycznym i farmaceutycznym oraz jako dodatek do pasz dla zwierząt. Głównie wykorzystuje się ją do produkcji koncentratów spożywczych, produktów mlecznych, cukierniczych i piekarskich oraz produktów rybnych czy mięsnych [19].

Do polisacharydów niecelulozowych zalicza się hemicelulozy. Należą one do materiałów zapasowych znajdujących się w ścianach komórkowych roślin pomiędzy fibrylami. W skład hemiceluloz wchodzą: mannany, galaktomannany, ksylany, arabinoksylany. Spośród hemiceluloz wyróżnić można hemicelulozy rozpuszczalne w wodzie oraz hemicelulozy rozpuszczalne w kwasach. W przewodzie pokarmowym człowieka hemicelulozy nie są trawione przez enzymy pokarmowe, natomiast ulegają niecałkowitej degradacji w wyniku działania bytujących w przewodzie pokarmowym bakterii. Dzięki temu zwiększają absorbowanie wody i niektórych jonów metali [11, 16, 29, 46].

Do składników błonnika pokarmowego zalicza się również ligninę $[9,16]$. Należy ona do pochodnych hydroksyfenylopropanu i nie jest związkiem węglowodanowym. Znajduje się ona wraz z celulozą w komórkach roślinnych. Lignina nie podlega degradacji $\mathrm{w}$ jelicie grubym w wyniku działania bytujących tam bakterii. Wykazuje zdolność wiązania wolnych rodników, soli kwasów żółciowych i wody, ale może również utrudniać wchłanianie z przewodu pokarmowego niektórych składników odżywczych. Ponadto jest odporna na enzymatyczną i chemiczną hydrolizę.

Pektyny należą do polisacharydów niecelulozowych występujących naturalnie w ścianach komórek roślin lądowych i pełniących w nich funkcje strukturalne. Wyróżnia się substancje pektynowe takie, jak protopektyna - substancja nierozpuszczalna w wodzie, z której poprzez działanie na nią kwasów lub enzymu protopektynazy uwalniane są właściwe pektyny. Pektyny dzieli się na dwie grupy: pektyny wysokometylowane i pektyny niskometylowane. [12, 29]. Pektyny wysokometylowane mają zdol- 
ność do tworzenia żeli w roztworach o stężeniu cukru powyżej $60 \%$ oraz o pH poniżej 3,5 , natomiast pektyny niskometylowane wykazują tę zdolność niezależnie od stężenia cukrów zarówno w obojętnych, jak i lekko kwaśnych roztworach. Substancje pektynowe są mieszaniną pektyn z heksozami i pentozanami. Kwasy pektowe utworzone są z koloidalnych kwasów poligalakturonowych zestryfikowanych w małym stopniu lub niezestryfikowanych. Kwasy pektynowe są koloidalnymi kwasami poligalkakturonowymi częściowo zestryfikowanymi alkoholem metylowym. Kwasy pektowe nie biorą udziału w tworzeniu żeli z kwasami, cukrem lub z jonami metali. Kwasy pektynowe tworzą żele z kwasami i cukrem $[12,16]$. Swoje wielostronne zastosowanie w przemyśle spożywczym pektyny zawdzięczają zdolności zamiany zolu w żel. Jak podkreślają Mitek i Gasik [30], dzięki tej zdolności pektyn powstają trójwymiarowe struktury utrzymujące wodę oraz rozpuszczone w wodzie składniki ekstraktowe.

Górecka i Anioła [16] uważają, że polisacharydy roślin morskich najczęściej kojarzone są z polisacharydami alg. Występują w wodorostach i roślinach morskich jako alginiany. Stanowią jeden ze składników ścian komórkowych brunatnych glonów głównie Phaeophycae. Alginiany odgrywają bardzo ważną rolę zagęszczającą i stabilizującą. Alginiany w formie soli magnezu, sodu, potasu czy amonu są bardzo dobrze rozpuszczalne. Wykorzystywane są jako substytut tłuszczu, przy czym nie zmieniają cech sensorycznych i tekstury gotowego produktu.

Karageny należą do hydrokoloidów i znajdują się głównie w czerwonych glonach Rhodophyceae. Różnią się od siebie budową łańcucha polisacharydowego. Znane są cztery typy karagenów: $\kappa$ I, $\kappa$ II, I i $\lambda$, wykorzystywane głównie jako stabilizatory i substancje zwiększające lepkość w zawiesinach i emulsjach [45].

Wśród frakcji błonnika pokarmowego do polisacharydów niecelulozowych zaliczane są również gumy i śluzy roślinne. Składają się z kwasu glukuronowego, mannozy, ksylozy i arabinozy. Gumy, podobnie jak i śluzy roślinne, należą do polisacharydów o rozgałęzionej strukturze. Gumy są wydzielinami powstałymi na skutek uszkodzenia roślin. Natomiast śluzy znajdują się w endospermie roślin i pomagają im w utrzymywaniu wody, jak również zabezpieczają nasiona przed wysychaniem [8].

Do polisacharydów modyfikowanych technologicznie zalicza się skrobię, która jest węglowodanem dostarczającym ok. $4 \mathrm{kcal} \mathrm{z} 1 \mathrm{~g}$, dzięki czemu może być źródłem niezbędnej energii dla organizmu. Jest hydrolizowana przez enzymy amylolityczne przewodu pokarmowego do glukozy, a następnie w tej postaci wchłaniana w jelicie cienkim. Z tego względu zalicza się skrobię do związków całkowicie i szybko trawionych. Dotyczy to jednak tylko skrobi poddanej obróbce cieplnej przy odpowiedniej ilości wody, czyli w postaci skleikowanej, bezpośrednio po przygotowaniu $[7,11]$. W formie nieskleikowanej skrobia niektórych odmian roślin, np. zbóż, może nie podlegać całkowitemu strawieniu w organizmie człowieka. Skrobia oporna (RS - resistant starch) nie jest całkowicie trawiona. Pozostając w formie nienaruszonej lub jako pro- 
dukt częściowej hydrolizy, pomija jelito cienkie i przechodzi do jelita grubego. Skrobia oporna należy do polisacharydów zmienionych technologicznie i nie podlega procesom wchłaniania w jelicie cienkim $[6,26]$. Skrobia oporna tworzy się w czasie ogrzewania w niewielkiej ilości wody. Uszkodzone cząsteczki skrobi nie mają możliwości żelowania, przez co zmieniają się w związki oporne na działanie soków trawiennych. To właśnie chemiczne właściwości skrobi opornej decydują o zaliczeniu tego składnika do błonnika pokarmowego. Skrobia oporna jest również produkowana przemysłowo, a najczęściej używanymi surowcami do jej produkcji są skrobia ziemniaczana lub kukurydziana $[8,11,33]$.

\section{Preparaty błonnikowe}

Początkowo zastosowanie włókna pokarmowego do żywności związane było bardzo często z powstawaniem niekorzystnej tekstury produktu, która wpływała na zmianę smaku, pogorszenie konsystencji i struktury. Obecnie produkuje się preparaty błonnikowe, które korzystnie wpływają na teksturę gotowych wyrobów. Wynika to z jego bardzo dobrych właściwości funkcjonalnych, takich jak: wiązanie wody (zmniejszenie zjawiska synerezy), zastępowanie tłuszczu (obniżenie kaloryczności wyrobów), zwiększanie objętości produktów. Istotną właściwością preparatów błonnikowych jest także to, że powstałe produkty charakteryzują się neutralnym zapachem i smakiem $[13,20$, $29,36]$.

Preparaty błonnikowe występują najczęściej w formie proszków i granulatów o zróżnicowanym rozdrobnieniu. Wyróżnia się ponadto oczyszczone otręby, syropy, tabletki i kapsułki, które mogą być bezpośrednio spożywane przez konsumentów. Do produkcji preparatów błonnikowych najczęściej stosowane są:

- otręby (np. jęczmienne, pszenne, kukurydziane, ryżowe i owsiane),

- plewy i słoma,

- kolby kukurydzy,

- rośliny strączkowe (najczęściej soja i groch),

- rośliny okopowe (np. ziemniaki, buraki cukrowe, buraki ćwikłowe),

- przemysłowe odpady owocowo-warzywne (np. odpady z przerobu marchwi, pomidorów, czarnej porzeczki, ogórków czy wytłoków jabłkowych).

Preparaty błonnikowe muszą charakteryzować się określonymi cechami $[2,13$,

20]:

- minimalną zawartością pestycydów i metali ciężkich,

- dużą zawartością składników bioaktywnych,

- dużą zawartością błonnika pokarmowego,

- brakiem negatywnego oddziaływania na cechy sensoryczne żywności, 
- nadawaniem dodatkowej trwałości produktom,

- niską ceną.

\section{Zastosowanie błonnika pokarmowego w projektowaniu i wzbogacaniu produktów żywnościowych}

Dynamizacja przemysłu spożywczego w szeroko rozumianym projektowaniu i wzbogacaniu żywności jest elementem rywalizacji zarówno pomiędzy branżami przemysłu spożywczego, jak i poszczególnymi producentami. Producenci dążą do zaoferowania konsumentom jak najszerszej gamy produktów korzystnych pod względem wartości odżywczej, właściwości prozdrowotnych i funkcjonalnych, o przedłużonym terminie przydatności do spożycia, a także atrakcyjnych cenowo. Taka strategia rynkowa pozwala zdobyć przewagę konkurencyjną, jak również promować stosowanie najnowszych rozwiązań technologicznych $[9,17,40]$.

Wymagania rynkowe wymuszają na producentach żywności wprowadzanie do obrotu produktów, które odpowiadają na potrzeby konsumentów. Jak podają Moczkowska i wsp. [31], widoczny jest trend wyboru przez kupujących produktów żywnościowych określanych jako naturalne czy też prozdrowotne. Do ich produkcji coraz częściej stosuje się substancje dodatkowe o odpowiednich właściwościach. Przykładem takiej substancji jest błonnik pokarmowy, chętnie wybierany przez producentów żywności, ale również przez konsumentów uznających go za prozdrowotny składnik żywności $[9,17,27,31,40]$. Wzbogacanie żywności w błonnik pokarmowy wiąże się z zastosowaniem rozwiązań technologicznych, które umożliwiają uzyskanie produktów o wysokiej koncentracji tego składnika, ale nie wpływają na pogorszenie cech sensorycznych i funkcjonalnych $[15,27]$.

Jednym z ważniejszych czynników mających wpływ na zastosowanie preparatów błonnikowych w żywności jest stopień rozdrobnienia błonnika i jego skład frakcyjny. Jak twierdzi Górecka [15], wpływając technologicznie na stopień rozdrobnienia włókna pokarmowego, ingeruje się w jego właściwości funkcjonalne, co może mieć wpływ na oddziaływanie błonnika pokarmowego na przewód pokarmowy człowieka. Niezbędne staje się zatem modyfikowanie procesów technologicznych.

Do najbardziej skoncentrowanych źródeł włókna pokarmowego należą zboża, przy czym w produktach zbożowych zawartość tego składnika jest często bardzo zróżnicowana, gdyż w czasie przemiału ziarna na mąkę bogate w błonnik pokarmowy składniki ziarna są eliminowane. Zabiegiem często stosowanym w technologii zbóż jest prażenie otrąb, dzięki czemu wzrasta zawartość frakcji ligninowej błonnika [23].

Ze względu na technologiczny, jak i żywieniowy aspekt racjonalnego żywienia, celowo dodaje się do pieczywa i wyrobów ciastkarskich takie surowce, w których zawartość błonnika pokarmowego jest stosunkowo duża. Najczęściej stosowanymi do- 
datkami są otręby, płatki zbożowe oraz preparaty błonnikowe, które mają wpływ na poprawę tekstury gotowego produktu, jak również mogą mieć wpływ na zwiększenie objętości pieczywa. Jurga [23] oraz Tarrega i wsp. [42] podają, że mąki jasne, tj. pszenna i żytnia, zawierają małe ilości błonnika pokarmowego, dlatego stosuje się je do produkcji pieczywa i wyrobów ciastkarskich. Współcześnie miesza się mąki jasne i razowe $\mathrm{z}$ wysokobłonnikowymi preparatami. Poprzez dodatek otrąb pszennych w ilości $10 \div 15 \%$ zwiększa się wodochłonność (o $3 \div 5 \%$ ) oraz wydajność masowa (wzrasta nawet o $2 \%$ ) [23, 37].

Możliwe jest również częściowe zastąpienie tłuszczu w produktach ciastkarskich i piekarskich błonnikiem pokarmowym. Górecka [15] zauważa, że pączki z dodatkiem błonnika pokarmowego charakteryzują się mniejszą zawartością tłuszczu, większą sprężystością, jędrnością oraz objętością w porównaniu z tymi tradycyjnie sporządzanymi, natomiast dodatek błonnika pokarmowego do ciastek intensyfikuje zdolność zatrzymywania wody o ponad $120 \%$. Moczkowska i wsp. [31] wykazali, że dodatek błonnika pokarmowego uzyskanego z jabłek i owoców cytrusowych wpływa na poprawę cech sensorycznych ciastek, a zastąpienie cukru dodatkiem błonnika w ilości $25 \%$ pozwala na zwiększenie w nich zawartości wody. Ponadto zastosowanie dodatku błonnika pokarmowego opóźnia proces czerstwienia pieczywa [10,31].

Jak podaje Hać-Szymańczuk [20], preparat błonnikowy pochodzący z wycierki ziemniaczanej używany jest do modyfikowania ciasta skrobiowego, gdyż nie powoduje on zmian fizykochemicznych i sensorycznych pieczywa. Także półprodukty ekstrudowane typu pellets z dodatkiem preparatów błonnikowych w ilości 5 i $10 \%$ nie wykazują niekorzystnych zmian tekstury. Wzrost zawartości błonnika pokarmowego wpływa korzystnie na twardość chrupek i ogranicza ilość tłuszczu [20].

Jurga [24] wskazuje, że dodatek błonnika pszennego w ilości $6 \%$ do wyrobów makaronowych wpływa korzystnie na właściwości kulinarne, tj. wytrzymałość na rozgotowanie. Błonnik pokarmowy jest również bardzo dobrym dodatkiem do zup typu instant, sosów oraz mieszanek przyprawowych. Zapobiega on zbryleniu produktu, wspomaga utrzymywanie wody oraz kształtuje prawidłową teksturę wyrobów [15].

W ostatnich latach do żywności funkcjonalnej zalicza się również wiele przetworów mięsnych. Możliwość produkcji przetworów mięsnych z dodatkiem błonnika pokarmowego wynika zarówno z jego technologicznych właściwości, jak również z jego niedoborów w diecie [20,35]. Do produkcji przetworów mięsnych najczęściej stosowany jest dodatek błonnika ziemniaczanego, jęczmiennego, pszennego i owsianego.

Błonnik ziemniaczany cechuje się wieloma pożądanymi właściwościami. Umożliwia obniżenie wartości energetycznej produktu, zaś pod względem technologicznym jego obecność w produkcie przyczynia się do ograniczania absorpcji tłuszczu w czasie smażenia, polepszania retencji i wiązania wody, a także redukowania strat masy podczas obróbki cieplnej [20]. W procesie technologicznym błonnik ziemniaczany doda- 
wany jest w początkowym etapie produkcji, tj. w czasie kutrowania mięsa. HaćSzymańczuk [20] podaje, że błonnik ziemniaczany pozytywnie oddziałuje na teksturę produktów w czasie ich chłodniczego przechowywania. Wyciek wody w opakowaniach zostaje zminimalizowany przez dodatek błonnika ziemniaczanego. Stosowanie błonnika ziemniaczanego do produktów mięsnych w ilości $1 \div 4 \%$ nie powoduje pogorszenia właściwości, zarówno w trakcie mrożenia, jak i rozmrażania, a cechy sensoryczne błonnika (smak i zapach) nie są odczuwane w gotowym produkcie. Błonnik ziemniaczany najczęściej stosowany jest w przemyśle do mięsa mielonego, kutrowanych kiełbas poddawanych parzeniu oraz do hamburgerów [3, 5, 35].

Błonnik jęczmienny charakteryzuje się dużą zawartością nierozpuszczalnych i rozpuszczalnych polisacharydów o dużej lepkości. Ze względu na brązową barwę stosowany jest jako dodatek do mięsa mielonego oraz do wyrobu pasztetów.

Błonnik pszenny pozyskiwany jest ze słomy. Preparaty błonnika pszennego odznaczają się jego dużą zawartością, nie mniejszą niż 97 \%. Jest on całkowicie obojętny pod względem zapachu i smaku. Błonnik pszenny jest neutralny w stosunku do składników i dodatków do żywności, do której jest stosowany. Preparat błonnika pszennego charakteryzuje się bardzo dużą zdolnością wiązania tłuszczu i wody, dzięki czemu wpływa na polepszenie odczucia zwięzłości przetworów mięsnych w trakcie gryzienia. Zapobiega on również uwalnianiu tłuszczu i wody podczas obróbki cieplnej. Z kolei podczas kutrowania polepsza ich retencję. Takie właściwości błonnika pszennego wpływają na polepszenie soczystości i tekstury, ograniczają znacznie ubytki masy w trakcie obróbki termicznej a także przedłużają trwałość gotowego produktu [34, 39]. Preparaty błonnika pszennego najczęściej wykorzystywane są do produkcji kiełbas suszonych, kiełbas kutrowanych parzonych, kiełbas w puszce, wędzonek i do produkcji innych wyrobów z mięsa rozdrobnionego [3, 34, 35].

Błonnik owsiany pozyskiwany jest z nasion owsa. Pod względem właściwości porównywalny jest do błonnika jęczmiennego. Charakteryzuje się jasnożółtą barwą i obojętnym smakiem. Szczególnie ważną technologicznie rolą błonnika owsianego jest wiązanie bardzo dużych ilości wody (w granicach $800 \%$ ). Wpływa on także korzystnie na teksturę i prawidłowe emulgowanie tłuszczów. Stosowany jest zazwyczaj do kutrowanych przetworów mięsnych $[5,20]$. Błonnik owsiany odgrywa szczególną rolę w przemyśle mleczarskim - zwłaszcza $\beta$-glukany należące do frakcji rozpuszczalnej włókna pokarmowego. $\beta$-glukany stosowane są do jogurtów o obniżonej zawartości tłuszczu, a także do produkcji lodów. Ich dodatek poprawia właściwości sensoryczne poprzez wywoływanie odczucia tzw. „pełności w ustach”. Dodatek $\beta$-glukanyów do serów solankowych o obniżonej zawartości tłuszczu powoduje podwyższenie ilości kwasów octowego, mlekowego i masłowego podczas dojrzewania, a także modyfikuje aromat produktów. Dodatek preparatów na poziomie 0,7 i 1,4 \% wpływa na zmniej- 
szenie twardości serów, co przyczynia się do zbliżenia ich jakości do serów pełnotłustych $[1,14,43,46]$.

\section{Podsumowanie}

Coraz większa wiedza konsumentów na temat korzystnego oddziaływania żywności funkcjonalnej na organizm człowieka przyczynia się do jej spożywania, co sprawia, że staje się ona istotnym segmentem rynku żywności. Konsument nabywający produkty należące do kategorii żywności funkcjonalnej oczekuje, że ich spożycie przyczyni się do lepszego funkcjonowania jego organizmu. Żywność funkcjonalna musi więc zawierać składniki, które korzystnie wpływają na fizjologiczne funkcje organizmu, a efekt działania tych substancji powinien wykraczać poza wartość odżywczą, która jest typowa dla żywności tradycyjnej.

Wprowadzenie składników bioaktywnych, w tym błonnika pokarmowego, do produktów żywnościowych pozwala na podniesienie jakości zdrowotnej żywności. Błonnik pokarmowy jest ważnym składnikiem bioaktywnym, który odgrywa istotną rolę w racjonalnym żywieniu, a także w leczeniu i prewencji wielu chorób. Jego działanie sprowadza się głównie do regulowania perystaltyki jelit, zapobiegania zaparciom, usuwania z organizmu toksyn i produktów przemiany materii, a w konsekwencji do zmniejszania ryzyka chorób nowotworowych, zwłaszcza jelita grubego. Dodatek błonnika do produktów spożywczych powoduje obniżenie gęstości energetycznej pożywienia, a także wydłuża czas odczuwania sytości. Zwiększenie spożycia błonnika pokarmowego można osiągnąć poprzez dodatek do żywności preparatów wysokobłonnikowych. Preparaty zbożowe cechuje duża zawartość błonnika nierozpuszczalnego, natomiast preparaty pozyskiwane z owoców i warzyw charakteryzują się stosunkowo dużą zawartością błonnika rozpuszczalnego.

\section{Literatura}

[1] Akalın A.S., Kesenkas H., Dinkci N., Unal G., Ozer E., Kınık O.: Enrichment of probiotic ice cream with different dietary fibers: Structural characteristics and culture viability. J. Dairy Sci., 2018, 101 (1), 37-46.

[2] Anioła J., Piotrowska E., Walczak K., Górecka D.: Zastosowanie mikronizowanych preparatów wysokobłonnikowych w wyrobach ciastkarskich. Żywność. Nauka. Technologia. Jakość, 2008, 4 (59), 103-110.

[3] Biswas A.K., Kumar V., Bhosle S., Sahoo J., Chatli M.K.: Dietary fibers as functional ingredients in meat products and their role in human health. Int. J. Livestock Production, 2011, 2 (4), 45-54.

[4] Borycka B.: Jakość zdrowotna nowych rodzajów żywności. Problemy Jakości, 2010, 4, 15-20.

[5] Cegiełka A., Włoszczuk K., Miazek J., Hać-Szymańczuk E.: Wpływ preparatu błonnika owsianego Vitacel HF 600 na jakość hamburgerów wołowo-wieprzowych. Zesz. Probl. Post. Nauk Rol., 2015, $583,35-43$. 
[6] Cygan P., Waszkiewicz-Robak B., Świderski F.: Żywność funkcjonalna - przyszłość, perspektywy, trendy. Przem. Spoż., 2003, 57, 12-15.

[7] Czerwińska D.: Oporna skrobia w produktach piekarskich. Przegl. Zboż. Młyn., 2011, 55 (08), 9-10.

[8] Czerwińska D.: Produkty zbożowe źródłem składników mineralnych w diecie. Przegl. Zboż. Młyn., 2012, 56 (6), 2-4.

[9] Dłużewska E., Florowska A.: Nowoczesne substancje strukturotwórcze. Przem. Spoż., 2010, 64, 811.

[10] Elleuch M., Bedigian D., Roiseux O., Besbes S., Blecker C., Attia H.: Dietary fibre and fibre-rich by-products of food processing: Characterisation, technological functionality and commercial applications: A review. Food Chem., 2011, 124 (2), 411-421.

[11] Fuller S., Beck E., Salman H., Tapsell L.: New horizons for the study of dietary fiber and health: A review. Plant Foods Hum Nutr, 2016, 71 (1), 1-12.

[12] Gasik A., Mitek M.: Zastosowanie preparatów pektynowych. Przegl. Piek. Cuk., 2013, 61 (3), 1821.

[13] Gąsiorowski H.: Kukurydza. Część 3. Błonnik pokarmowy. Przegl. Zboż. Młyn., 2008, 52 (1), 2425.

[14] Gibiński M.: $\beta$-glukany owsa jako składnik żywności funkcjonalnej. Żywność. Nauka. Technologia. Jakość, 2008, 2 (57), 15-29.

[15] Górecka D.: Błonnik pokarmowy. Znaczenie żywieniowe i technologiczne. Przegl. Zboż. Młyn., 2008, 52 (11), 23-26.

[16] Górecka D., Anioła J.: Błonnik pokarmowy i preparaty wysoko błonnikowe. W: Współczesna wiedza o węglowodanach. Red. J. Gawęcki. Wyd. AR w Poznaniu, Poznań 1998, ss. 56-60.

[17] Górecka D., Anioła J.: Kierunki wykorzystania preparatów błonnikowych w przemyśle spożywczym. Przem. Spoż., 1999, 53, 46-49.

[18] Grajeta H.: Żywność funkcjonalna w profilaktyce chorób układu krążenia. Adv. Clin. Exp. Med., 2004, 13 (3), 503-510.

[19] Grodzka K., Krygier K.: Celuloza i jej pochodne jako dodatki do żywności. Przem. Spoż., 2004, 8 (58), 44-48.

[20] Hać-Szymańczuk E.: Wykorzystanie preparatów błonnikowych w przemyśle spożywczym. Przem. Spoż., 2006, 60, 34-36.

[21] Jarczyk A., Berdowski J.B.: Przetwórstwo owoców i warzyw. WSiP, Warszawa 1999, ss. 20-51.

[22] Jarosz M., Rychlik E., Stoś K., Wierzejska R., Wojtasik A., Charzewska J., Chwojnowska Z.: Normy żywienia dla populacji Polski. IŻŻ, Warszawa 2017.

[23] Jurga R.: Błonnik pokarmowy - wzbogacanie produktów zbożowych. Przegl. Zboż. Młyn., 2010, 54 (9), 26-29.

[24] Jurga R.: Wzbogacanie makaronów dodatkami z błonnikiem pokarmowym. Przegl. Zboż. Młyn., 2008, 3 (52), 10.

[25] Krygier K., Florowska A.: Żywność funkcjonalna obecnie i w przyszłości. Przem. Spoż., 2008, 62 (5), 2-6.

[26] Leszczyński W.: Skrobia oporna i jej znaczenie. Przeg. Piek. Cuk., 2004, 52 (7), 2-5.

[27] López-Marcos M.C., Bailina C., Viuda-Martos M., Pérez-Alvarez J.A., Fernández-López J.: Properties of dietary fibers from agroindustrial coproducts as source for fiber-enriched foods. Food Bioprocess Technol., 2015, 8 (12), 2400-2408.

[28] Martirosyan D.M., Singh J.: A new definition of functional food by FFC: What makes a new definition unique? Functional Foods in Health and Disease, 2015, 5(6), 209-223.

[29] Mehta N., Ahlawat S.S., Sharma D.P., Dabur R.S.: Novel trends in development of dietary fiber rich meat products - a critical review. J. Food Sci. Technol., 2015, 52 (2), 633-647.

[30] Mitek M., Gasik A.: Pektyny - błonnik rozpuszczalny. Przegl. Piek. Cuk., 2013, 2, 20-21. 
[31] Moczkowska M., Półtorak A., Wyrwisz J.: Wpływ trendów żywieniowych na projektowanie nadziewanych zbożowych produktów spożywczych. Post. Techn. Przetw. Spoż., 2014, 2, 136-142.

[32] Nowak K., Żmudzińska-Żurek B.: Błonnik - niezbędne włókno roślinne. Przem. Ferm. Owoc. Warz., 2008, 7 (8), 16-19.

[33] Orłowska M.: Budowa i właściwości skrobi w świetle najnowszych badań Cz. I. Przegl. Piek. Cuk., 2008, 56 (2), 14, 16-17.

[34] Piotrowska E., Szczepaniak B., Dolata W.: Wpływ częściowej zamiany tłuszczu błonnikiem na cechy sensoryczne wędlin drobno rozdrobnionych. Część 2. Gosp. Mięs., 2008, 60 (9), 14-18.

[35] Przybylski W., Kajak-Siemaszko K., Jaworska D., Szymczyk E., Sałek P.: Zastosowanie błonnika pokarmowego o zróżnicowanej długości włókien do podwyższenia jakości wędlin wyprodukowanych z mięsa wadliwego. Żywność. Nauka. Technologia. Jakość, 2018, 2 (115), 34-47.

[36] Rafalska U., Łopacka J., Żontała K., Sakowska A., Lipińska A.: Błonnik pokarmowy w przemyśle mięsnym - funkcje technologiczne i zdrowotne. Prob. Hig. Epidemiol., 2015, 96 (4), 713-718.

[37] Różyło R.: Zmiany cech tekstury miękiszu chleba pszennego pod wpływem dodatku produktów z owsa. Acta Agrophysica, 2007, 10 (3), 667-676.

[38] Sivaprakasam S., Gurav A., Paschall A.V., Coe G.L., Chaudhary K., Cai Y., Shi H.: An essential role of Ffar2 (Gpr43) in dietary fibre-mediated promotion of healthy composition of gut microbiota and suppression of intestinal carcinogenesis. Oncogenesis, 2016, 5 (6), \# 238.

[39] Słowiński M., Jankiewicz L.: Mięso i przetwory mięsne żywnością funkcjonalną. Gosp. Mięs., 2011, $5,18-22$.

[40] Stankiewicz D.: Nowa żywność. Analizy BAS, 2014, (13), 1-9.

[41] Świderski F., Waszkiewicz-Robak B.: Składniki bioaktywne w żywności funkcjonalnej. Przem. Spoż., 2005, 59 (4), 20-22.

[42] Tarrega A., Quiles A., Morell P., Fiszman S., Hernando I.: Importance of consumer perceptions in fiber-enriched food products. A case study with sponge cakes. Food Function, 2017, 8 (2), 574-583.

[43] Volikakis P., Biliaderis C., Vamwakas C., Zerfiridis G.: Effect of a commercial oat beta-glucan concentrate on the chemical, physicochemical and sensory attributes of a low-fat white-brined cheese product. Food Res. Int., 2004, 1 (37), 83-94.

[44] Westenbrink S., Brunt K., van der Kamp J.W.: Dietary fibre: Challenges in production and use of food composition data. Food Chem., 2013, 140 (3), 562-567.

[45] Zychnowska M., Onacik-Gür S., Krygier K.: Właściwości i możliwości wykorzystania zamienników tłuszczów dostępnych na rynku. Probl. Hig. Epidemiol., 2015, 96 (1), 42-50.

[46] Żulewska J.: Produkty mleczne nośnikami składników prozdrowotnych. Przem. Spoż., 2013, 67 (4), 14-18.

[47] Kołodziejczyk P., Michniewicz J.: Ziarno zbóż i produkty zbożowe jako źródła błonnika pokarmowego. Żywność. Nauka. Technologia. Jakość, 2018, 3 (116), 5-22.

[48] Rozporządzenie (WE) nr 1924/2006 Parlamentu Europejskiego i Rady z dnia 20 grudnia 2006 r. w sprawie oświadczeń żywieniowych i zdrowotnych dotyczących żywności. Dz. U. L 404, ss. 9-25, z 30.12.2006.

\section{POSSIBLE APPLICATIONS OF DIETARY FIBRE IN FUNCTIONAL FOOD PRODUCTION}

$$
\text { S u m m a r y }
$$

The reinvigoration of food industry in the field of designing new or enriched foods and expanding product ranges is an element of competition between both the food industry branches and the individual producers. Food producers endeavour to offer consumers the widest possible range of products that are 
advantageous in terms of their nutritional properties, health promoting properties, extended shelf life and attractive prices. This market strategy makes it possible to gain a competitive advantage and to promote the applications of the most recent technological solutions. The increased interest and awareness of consumers in the area of proper nutrition caused the quality requirements, including the nutritional value of foods, to increase. This requires necessary changes in the production processes so as to ultimately satisfy as many consumers as possible.

Dietary fibre exemplifies an ingredient that enriches foodstuffs and, recently, both the producers and the consumers are more and more interested in it; most of all, they consider it as a health-promoting food ingredient. Over the last century adding dietary fibre to food was very often associated with the development of disadvantageous texture of the product. Now modern cellulose preparations are produced that have a positive effect on the texture, functional and sensory properties of food, and which are characterized, among others, by the following properties: water binding capacity, increasing the volume of products, neutral smell and taste, or the possibility of being used as a fat substitute. The paper covers the history and breakdown of functional food, the definition and breakdown of dietary fibre; also the possible applications are discussed of this ingredient when designing and enriching food products.

Key words: functional food, bioactive ingredients, dietary fibre, fibre preparations, designing food 